nych narzędzi zarządzania dokumentacją”. Dalszą część warsztatów zdominowały prezentacje. Grzegorz Gałęzowski, informatyk z AP w Lublinie, mówił o „Skutecznym przechowywaniu zasobów cyfrowych”. Rafał Magryś, pracownik NAC, omówił budowę archiwum elektronicznego, ilustrując wystąpienie przykładem swojej macierzystej placówki. Poprowadził on także zajęcia warsztatowe 14 kwietnia. Zapoznał wówczas studentów z Systemem Informacji Archiwalnej ZoSIA ${ }^{4}$.

Podczas II Radzyńskich Warsztatów Archiwalnych D. Magier stwierdził: „Znaczne rozszerzenie zakresu warsztatów w porównaniu z ubiegłorocznym zjazdem bardzo raduje organizatorów. Radzyńskie Warsztaty Archiwistyczne wyrastają na drugą co do skali przedsięwzięcia imprezę studenckich kół naukowych archiwistów w Polsce po dorocznym Ogólnopolskim Zjeździe Studentów Archiwistyki, stają się sztandarowym przedsięwzięciem radzyńskiego oddziału archiwum państwowego" ${ }^{5}$. Należy więc spodziewać się, że warsztaty będą nadal organizowane w kolejnych latach, coroczni adepci będą mieć szansę na szlifowanie swojego warsztatu i integrację z przedstawicielami środowiska archiwalnego, zarówno akademickiego, jak i studenckiego.

Damian Sitkiewicz

\title{
XII Ogólnopolski Zjazd Studentów Archiwistyki
}

WW dniu 23 kwietnia 2009 r., podczas XI Ogólnopolskiego Zjazdu Studentów Archiwistyki w Katowicach, przedstawiciele studenckich archiwalnych kół naukowych zdecydowali o powierzeniu organizacji następnego spotkania Kołu Naukowemu Studentów Archiwistyki Uniwersytetu Wrocławskiego. Profesjonalne przygotowanie katowickiego zjazdu spowodowało, że przed organizatorami kolejnego dorocznego spotkania stanęło niełatwe zadanie, a zarazem duże wyzwanie przygotowania co najmniej porównywalnej pod względem naukowym i logistycznym konferencji, gromadzącej studentów archiwistyki z całego kraju.

Pierwsze kroki i działania związane z organizacją XII OZSA we Wrocławiu zostały podjęte w drugiej połowie 2009 r. KNSA UWr zwróciło się wówczas o objęcie honorowego patronatu nad konferencją do Marka Łapińskiego

4 Cyfrowy Radzyń, Wspólnota Radzyńska, nr 16 z 20 IV 2010, s. 8.

5 Zarządzajacy dokumentacją będą integrować się w Radzyniu, Wspólnota Radzyńska, nr 17 z 23 IV 2008, s. 7. 
(marszałka województwa dolnośląskiego), Sławomira Radonia (Naczelnego Dyrektora Archiwów Państwowych), Elżbiety Kościk (dziekana Wydziału Nauk Historycznych i Pedagogicznych UWr), Rościsława Żerelika (dyrektora Instytutu Historycznego UWr), Jarosława Porazinskiego (prezesa SAP), Włodzimierza Sulei (dyrektora wrocławskiego oddziału Instytutu Pamięci Narodowej) oraz do Józefa Drozda (dyrektora AP we Wrocławiu). Wszyscy zaproszeni wyrazili zgodę na objęcie Zjazdu swym patronatem. Równolegle zostały wystosowane zaproszenia do uczestnictwa we wrocławskim spotkaniu do studentów archiwistyki na uniwersytetach w Gdańsku, Katowicach, Kielcach, Lublinie, Poznaniu, Szczecinie, Toruniu oraz w akademiach w Siedlcach i Częstochowie. Zgłoszenia udziału napłynęły ze wszystkich wymienionych uczelni.

Wieczorem 20 kwietnia 2010 r., w dniu poprzedzającym oficjalne otwarcie XII OZSA, odbyło się nieformalne spotkanie młodych adeptów archiwistyki, które zostało połączone ze spacerem szlakiem mostów stolicy Dolnego Śląska. Oficjalne otwarcie Zjazdu nastąpiło 21 kwietnia o godzinie 10. Przybyłych do Wrocławia studentów archiwistyki podczas inauguracji XII Zjazdu swoją obecnością zaszczycili m.in. dyrektor wrocławskiego archiwum państwowego J. Drozd oraz zastępca dyrektora IH UWr Przemysław Wiszewski. Skierowali oni do zgromadzonych referentów i uczestników dorocznego spotkania ciepłe słowa, a Lucyna Harc, opiekun wrocławskiego KNSA, uroczyście uznała Zjazd za rozpoczęty. Inauguracyjny wykład zatytułowany „Problemy i wyzwania stojące przed archiwami w Polsce. Kilka uwag z perspektywy uniwersyteckiej” wygłosił Stanisław Jujeczka. Po oficjalnej części nastąpiło spotkanie przy lunchu połączone z kuluarowymi rozmowami.

Popołudniowe obrady odbywały się w dwóch równoległych sekcjach, z których pierwsza, zatytułowana „Archiwa i archiwiści”, była poświęcona problematyce związanej z działalnością bieżącą i rysem historycznym wybranych archiwów. Podczas tego panelu usłyszeliśmy m.in. referat dotyczący archiwów parafialnych, wygłoszony przez Marcina Jakubika (Akademia Podlaska w Siedlcach), jak również zostaliśmy zapoznani przez Monikę Gellert (UAM) z historią i działalnością Archiwum Miasta Budapesztu. W sekcji drugiej wystąpienia skupiły się wokół dwóch wątków: „Nowoczesne technologie i zarządzanie dokumentacją” oraz „Edukacja archiwalna i popularyzacja archiwistyki”. Wystąpienia związane z pierwszym tematem pozwoliły bliżej poznać m.in. specyfikę zarządzania dokumentacją w Urzędzie Miasta Częstochowy, o czym mówiły Kinga Maciaszczyk i Marta Mysłek (Akademia im. Jana Długosza w Częstochowie), a Katarzyna Pepłowska (UMK) przybliżyła zagadnienia odnoszące się do archiwów cyfrowych. Ciekawe referaty zosta- 
ły wygłoszone $\mathrm{w}$ panelu związanym $\mathrm{z}$ edukacją archiwalną i popularyzacją archiwistyki - m.in. Magdalena Kucharska (piotrkowska filia Uniwersytetu Humanistyczno-Przyrodniczego w Kielcach) pokazała, jak przez wystawy wirtualne archiwa państwowe promują swój zasób.

Drugiego dnia zjazdu kontynuowano panel „Archiwa i archiwiści”, podczas którego m.in. Katarzyna Ćwikła (UWr) przedstawiła referat o znajomości języków i rodzajów pisma w warsztacie archiwisty, a Jędrzej Szerle (UG) poruszył temat wzajemnych kontaktów, problemów i perspektyw na styku genealogii i archiwistyki. Natomiast w równolegle obradującej sekcji prelegenci podejmowali zróżnicowaną problematykę ujętą wspólnym tytułem „Zagadnienia archiwalne”. Łukasz Wróblewski (UMCS) omówił kwestie selekcji współczesnej dokumentacji samorządowej, a Anna Kubica i Kamila Skorupa (UŚl) zreferowały temat spuścizn archiwalnych jako źródła do badań nad życiem i działalnością wybitnych postaci na przykładzie pastora Franciszka Michejdy. W ciągu półtora dnia obrad wygłoszono łącznie 54 referaty. Ich zdecydowana większość miała wysoki poziom merytoryczny. Budujące były także niezwykle żywe dyskusje wokół wystąpień, co wskazywało na rzeczywiste zainteresowanie słuchaczy poruszanymi tematami. Dobre relacje panujące między uczestnikami stworzyły wyśmienitą atmosferę, co zaowocowało na zakończenie spotkania odnowieniem i podpisaniem przez szefów kół archiwalnych deklaracji o współpracy.

W trakcie zjazdu uczestnicy mieli możliwość wzięcia udziału w ponadtrzygodzinnych warsztatach archiwalnych. Do wyboru były warsztaty poprowadzone przez Grzegorza Waligórę z wrocławskiego IPN na temat „Zasób archiwalny IPN i jego zastosowanie w praktyce” oraz zajęcia przeprowadzone przez pracowników firmy archiwalnej CCA Europe.pl, zatytułowane „Zarządzanie dokumentacją w ramach programu ARCHIVOS”.

Ostatniego dnia konferencji studenci, którzy licznie dotarli do Wrocławia z odległych zakątków Polski, mieli okazję bliżej poznać dolnośląską stolicę. Mogli zobaczyć, jak prezentuje się w tej chwili, oraz dowiedzieć się więcej o jej bogatej i barwnej historii.

Dobromir Gierańczyk (Uniwersytet Wrocławski) 